\title{
Objectivity of Teachers' Assessment
}

\author{
Malá Eva ${ }^{1}$, Gadušová Zdenka ${ }^{2}$, Müglová Daniela ${ }^{2}$ \\ ${ }^{1}$ Ostrava University in Ostrava, Faculty of Education, Fr. Šrámka 3, 70900 Ostrava, Czech Republic \\ ${ }^{2}$ Constantine the Philosopher University in Nitra, Faculty of Arts, Štefánikova 67, 94901 Nitra, Slovakia
}

\begin{abstract}
School education and teachers are the constant focus of experts as well as the wider community who have tried, at least for the last 50-80 years, to introduce several reforms which would change and improve their system of education, including the Slovak one. The key factor in the system of education is, particularly, the teacher who should possess such qualities, abilities, skills and competences which enable the progress. But the problem is that the tools and criteria for teachers' assessment are not fully identified, and they are more focused on their teaching activities than on the educational outcomes of the activities - the process of learning. The paper presents partial findings of the research team based on the project APVV-14-0446 Evaluation of Teachers' Competences related to the teachers and head teachers perception of assessment viewed from four different perspectives: direct institutional assessment (internal and external), indirect institutional assessment (internal and external), optional assessment, and selfevaluation assessment.
\end{abstract}

Keywords - Competence, Assessment, Teacher, Head teacher, Inspector, Tools, Criteria

\section{Introduction}

The specification of the evaluation criteria for teachers' assessment is not a new issue in professional literature on teaching and its results. The need for an objective, holistic view of teacher's competence profile in the key scope of all the main

DOI: $10.18421 /$ SAR32-05

https://doi.org/10.18421/SAR32-05

Corresponding author: Eva Malá,

Ostrava University in Ostrava, Czech Republic.

Email: eva.mala@osu.cz

Received: 02 March 2020.

Revised: 08 June 2020.

Accepted: 16 June 2020.

Published: 30 June 2020.

(cc)Br-Nc-ND(C) 2020 Malá Eva, Gadušová Zdenka \& Müglová Daniela; published by UIKTEN. This work is licensed under the Creative Commons AttributionNonCommercial-NoDerivs 3.0 License.

The article is published with Open Access at www.sarjournal.com areas (educational impact on pupils, the efficiency of the teaching process, their own professional development) is still an up-to-date issue. So far, however, there is not such a system of evaluation that would take into consideration all the factors affecting teacher's work and at the same time guarantee the utmost objectivity. This reality was the incentive for initiation and development of the APVV-14-0446 project entitled Evaluation of Teachers' Competences, which was approved for financing by the Slovak Research and Development Agency in July 2015. In the initial phase of the project an extensive questionnaire survey focused on various aspects of teacher evaluation was carried out [1], [2]. It addressed primary and secondary school teachers and head teachers of all types of schools (education at ISCED 1,2 and 3). The aim of the paper is to provide the multifaceted assessment analysis of the data collected in the questionnaire survey on the assessed competence profile of teachers.

\section{Research Method}

The distribution of questionnaires was carried out at two levels: the questionnaires with identical questions (with only minor modifications) were targeted at the evaluators (head teachers) and the evaluated (teachers). The total number of respondents taking part in the questionnaires was 145 school head teachers and 670 teachers, which provides a valid sample for some generalizations [3].

Our concern, however, was not to design or review the existing evaluation criteria, but to look at selected aspects of the evaluation. We tried to summarize the basic indicators (who evaluates and how often the evaluation is done) that are inherent in the evaluation. At the same time we tried to map and interpret the positive and negative aspects of evaluation from the perspective of teachers and head teachers.

The evaluating perspectives were divided in terms of their structure into the following ones:

- direct institutional assessment, which is legislatively regulated as an obligatory duty of head teachers to evaluate teachers;

- indirect institutional assessment, i.e. institutional obligation without an explicit indication in the school legislation; 
- optional assessment;

- self-reflective assessment, i.e. teacher's own individual evaluation as a separate category.

Furthermore, as to the institutional evaluators, they can be divided into internal (a) and external (b) ones. This division turned out to be necessary just in terms of objectivity within evaluation perspectives.

\section{Research Findings}

\subsection{Direct Institutional Assessment}

\subsubsection{Internal}

This type of evaluation is legislatively embedded in and based on the Act $N^{\circ} 317 / 2009$ (from autumn 2019 the same obligations are anchored in the new Act $\mathrm{N}^{\circ}$ 138/2019) on teaching staff and other professional experts. It states the minimum frequency of the teachers' evaluation and the obligation of the assessor to inform the assessed teacher about the findings observed and recorded in the assessment process. The evaluation of teachers is expected to be done using internal assessment mechanisms designed by the school managers, or by the authorized members of school staff (for more details see [4], $[5],[6])$.

Internal evaluation is carried out by:

- the mentor-teacher who continuously evaluates the novice-teachers during the induction phase of their teaching career;

- the mentor-expert who continuously evaluates the novices during and at the end of their induction phase;

- the direct superior (school head teacher) of the teacher once a year, by the end of the school year at the latest.

As this evaluation is legislatively regulated, it is obligatory for the assessor. The Act explicitly states who and how often should be evaluated. When looking at the binding obligation to assess the one who is in a subordinate position, some disproportion between the desired state and reality can be observed (see Table 1). In our survey, 91 teachers (15\%) reported that their head teacher did not evaluate them at all, while 53 respondents (8\%) said they were evaluated less than once a year. It is of interest that in the questionnaire data from the head teachers no respondent stated that they did not assess their teachers at all.
Table 1. Assessment of teachers by school managers

\begin{tabular}{|c|c|c|c|c|c|c|c|c|}
\hline \multirow[t]{2}{*}{ 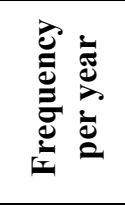 } & \multicolumn{2}{|c|}{ Not at all } & \multicolumn{2}{|c|}{$\begin{array}{c}\text { Less } \\
\text { than } \\
\text { once a } \\
\text { year }\end{array}$} & \multicolumn{2}{|c|}{$\begin{array}{c}\text { Once a } \\
\text { year }\end{array}$} & \multicolumn{2}{|c|}{$\begin{array}{c}\text { More } \\
\text { times per } \\
\text { year }\end{array}$} \\
\hline & $\mathbf{N}^{\circ}$ & $\%$ & $\mathbf{N}^{\circ}$ & $\%$ & $\mathbf{N}^{\circ}$ & $\%$ & $\mathbf{N}^{\circ}$ & $\%$ \\
\hline 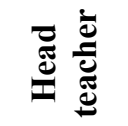 & 97 & 15 & 53 & 8 & 263 & 39 & 257 & 38 \\
\hline 롫 & 103 & 15 & 31 & 5 & 233 & 35 & 303 & 45 \\
\hline 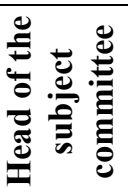 & 277 & 45 & 44 & 7 & 147 & 24 & 146 & 24 \\
\hline
\end{tabular}

In the interests of objectivity and to allow comparison, we present the frequency of evaluations conducted by other members of the school management to whom the head teacher can legitimately delegate their duty, as for example, to their deputies, other members of teaching staff who are considered to be experts in the field, or the representative of the advisory bodies of the school. This option was confirmed by $70 \%$ of head teachers. The absolute majority of the head teachers delegate this task to their deputies. Almost half of the respondents among teachers reported that the deputies of head teachers evaluated them quite frequently - more than once a year (45\%), and only $15 \%$ of the addressed teachers were not evaluated by the deputy head teachers at all. In oral comments on the selected items of the questionnaire, the head teachers called for legal delegation of the evaluation duties to their deputies.

The head teacher rarely delegates the evaluation duty to the head of the subject committee. However, the statistical data collected from the teachers in our survey showed that the head of the subject committee evaluates teachers quite often several times a year. This fact was stated by 202 teachers, i.e. 30\% of the teachers involved. Sporadically the assessment of teachers is carried out by other evaluators, too. The respondents stated that sometimes the head teacher had passed the assessment to the head of a methodology association, or to the chairperson of the school board.

In terms of feedback provision (see Table 2), 137 head teachers (94\%) stated that they informed the assessed teachers about the results of the evaluations; only 7 head teachers $(5 \%)$ reported that teachers were made aware of the evaluation conclusions occasionally and only one head teacher (1\%) stated that he never gave feedback to the evaluated teacher. 
In case when the head teacher delegates this competence to their deputies, the assessed teacher receives feedback less often - though in $77 \%$ of cases they always get it, but in $8 \%$ of cases only sometimes and in $15 \%$ of cases never. The situation is even worse if that task is delegated to the head of the subject committee, because according to the results of the survey he gives the feedback to the assessed teacher only in $49 \%$ of cases, in $10 \%$ of cases it happens sometimes and in $41 \%$ of cases never. The low provision of feedback by the deputy of the head teacher, and especially by the head of the subject committee, can be caused by the fact that they do not consider delegating the competence to assess the teacher as the integral part of their work duties and therefore they rather avoid giving feedback to the assessed teacher. They provide the head teacher with the assessment record and leave the feedback provision to the assessed teacher for the head teacher.

Table 2. Provision of feedback to the assessed teachers by school managers

\begin{tabular}{|c|c|c|c|c|c|c|}
\hline$\stackrel{20}{g} \stackrel{\Xi}{\Xi}$ & & & & nes & & \\
\hline ث: & $\mathbf{N}^{\circ}$ & $\%$ & $\mathbf{N}^{\circ}$ & $\%$ & $\mathbf{N}^{\circ}$ & $\%$ \\
\hline 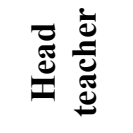 & 137 & 94 & 7 & 5 & 1 & 1 \\
\hline 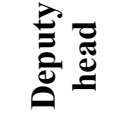 & 513 & 77 & 54 & 8 & 103 & 15 \\
\hline 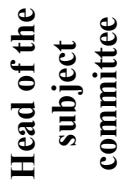 & 330 & 49 & 66 & 10 & 274 & 41 \\
\hline
\end{tabular}

\subsubsection{External}

External, out of school evaluators include governmental bodies, mainly the institute of school inspection. The external evaluation performed by the school inspection is governed by the Act No. $596 / 2003$ on state administration in education and education authorities, where in the Section 13 on the role of the state administration it is determined that the inspection (including the evaluation of teachers of different subjects) is performed by the State School Inspection through school inspectors to whom this task is delegated by the principal school inspector or the head of a school inspection centre. In the subject of religion and religious education the assessment task is delegated also to the authorized person of the relevant church or religious society.
The details of the organization of the school inspection and the procedures for its performance are described in the Decree of the Ministry of Education from 31 March 2005. According to $\S 3$, section 5 and $\S 37$ section 2 of the Act $\mathrm{N}^{\circ} 596 / 2003$ the inspection in schools and school institutions is normally carried out every six years. The Act also establishes an obligation to inform the direct superior (school head teacher) about the date, purpose and outcomes of the inspection. The assessors from the school inspectors in terms of provision of feedback to the assessed teachers (see Table 3) were pictured in our survey similarly as the heads of the subject committees ( $46 \%$ always give feedback to the evaluated person, $8 \%$ only sometimes and $46 \%$ never) - they rely on the head teachers to give feedback to the assessed teachers.

Table 3. Provision of feedback to the assessed teachers by inspectors

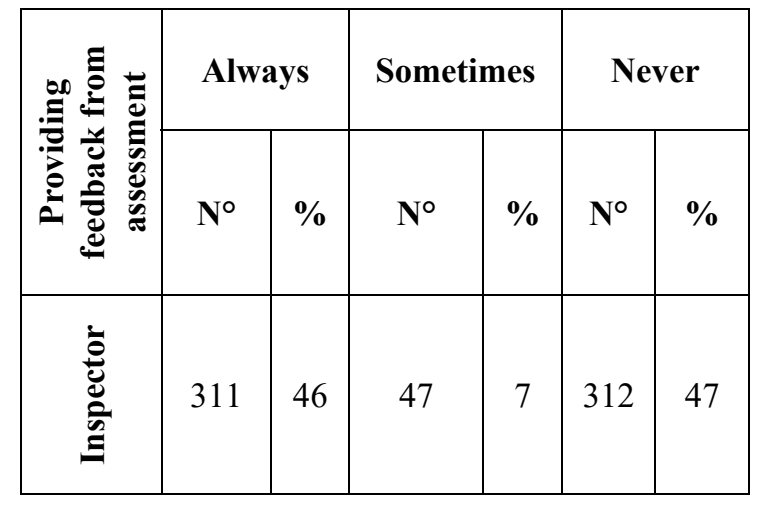

The assessment of head teachers is also regulated by the aforementioned Act. They are evaluated by the school establishing body, or, if the founder is a religious institution, then the assessor is the diocesan catechetical office. The evaluation is conducted by the institutional founder once a year.

\subsection{Indirect Institutional Assessment}

\subsubsection{Internal}

Internal evaluation of this kind is implemented by colleagues from the school teaching staff. For novice teachers in the induction phase of their career it is mainly the mentor teacher who takes on the assessing role. The need to initiate an evaluation exercise among colleagues is based either directly on the explicit wish of teachers to be monitored and assessed, or indirectly, as a proposal for giving a helping hand by senior colleagues. The implicit call for the evaluation as well as help from more experienced colleagues is usually expressed by novice teachers in the period of the induction phase of their teaching career. The initiative of this kind can also be the result of a critical self-reflection of experienced teachers who need advice and guidance 
from their didactically more creative colleagues. The respondents in our survey indicated this way of assessment very often. In many schools the members of the subject committee compile a schedule of mutual lesson observations. In terms of their frequency, the most common answer was "more than once a year" and "once a year".

\subsubsection{External}

External evaluation is carried out sporadically by an independent, non-profit organization with the aim of material assistance for a school. The teachers involved in the survey, for example, indicated the evaluation by the mentor of the LAEF (Latin Alamitos Education Foundation) organization. The external evaluators can occasionally be, as revealed by the survey, also colleagues from other schools who attend so called master classes several times a year.

\subsection{Optional Assessment}

The initiators and executors of this way of evaluation are parents and pupils. If a teacher does not directly ask for feedback, or either regarding the subjects performing evaluation, the evaluation is carried out spontaneously, with varying frequency. Respondents most often reported that their pupils and parents evaluated them several times a year.

\subsection{Self-evaluation assessment}

Self-reflective evaluation is another essential part of the evaluation process. The survey confirmed that teachers were aware of its importance and many of them also used it. They consider self-reflection to be a kind of a stress-free self-diagnostic option that offers them stress-free analysis and improvement of their own teaching. Specific and concrete ways and methods of self-assessment were, however, not the object of the survey. That is why it is questionable whether teachers understand this way of evaluation as an internal reflection on the management of their educational process in the form of sporadic intuitive self-reflexive questions, or whether they use more exact self-assessment tools or write their own selfreflexive diary.

\subsection{Assessment Objectivity}

The evaluators of all these aspects had one common goal: objective mapping of teacher's work, or their own educational activities. Although they shared the same effort, the ways of achieving targets were different.
The assessment includes a number of variables influencing both parties - the evaluator and the evaluated. It highly depends on the adequate selection of the evaluation criteria, assessment tools, assessment forms, and the ways of evaluation presentation, timing of the activity and, last but not least, the personality profile of both participating parties. Ideally, the evaluator is a competent, well prepared and psychologically mature individual, while the evaluated person is capable of the objective self-reflection, who perceives a possible constructive criticism as a tool for their career move and not as a discouraging or regressive element.

There is no doubt that each assessment always implies a subjective element. Slavík [7] defines evaluation as a highly demanding intellectual process that allows humans, based on the subjective approach, to distinguish in the external world important phenomena from the unimportant ones and among the important phenomena to distinguish constructive from the destructive ones. Assessment is an integral and inseparable part of values too; it is related to their awareness, discovery, highlighting, and observation or questioning and criticizing. The evaluator's subjective view of the evaluated as well as the subjective reaction of the evaluated to the conclusions of the evaluation process cannot be completely eliminated. On the other hand, penetration of the subjective factor into different evaluation perspectives is not identical. It makes a difference whether a teacher is assessed by an experienced methodologist qualified in the same subjects or by parents working in an entirely different professional field who clearly cannot meet the criterion of the professionally and didactically competent evaluator. Conversely, students and their legal representatives are, to put it in economic terms, the final purchasers of the teacher's educational efforts and their right to express evaluation cannot be denied. In the case of an incompetent evaluator, i.e. pupil/student, it is necessary to determine the precise evaluation criteria and to carry out evaluation in all parallel classes, and if it is possible, in different grades, in which the assessed teacher teaches the subject. When the evaluator is a parent and the teacher feels that unjustified criticism was expressed, the only thing which can help is factual and substantiated objection and contra-argumentation.

The subjectivity of a professionally competent evaluator may reflect mainly a personality profile and individual positive or negative attitude to the evaluated person. In real school conditions not only perfect notional constructs of the evaluator and the evaluated come into contact, as they have been described above, but real people with their strengths and weaknesses meet at a particular moment what, then, is influenced by their current physical and 
mental health. The definitely vague factor of "chemistry" between interacting parties also plays a certain role which operates in personal contacts subconsciously.

The acceptance of the subjective element in the evaluation, however, under no circumstances may undermine efforts for its objectivity. The main prerequisite of the evaluator is their awareness of the subjectivity and its reflection through selecting appropriate assessment criteria, argumentative reasoning of critical remarks and last, but not least, application of consciously rational approach to the evaluated person. Thus, they should aim to maximize the suppression of subjectivity in assessment.

The assessed person also has to make efforts to see things realistically, not to succumb to selfdelusion, suppress their own ego and self-reflectively consider the legitimacy of critical comments. In this context the statement of one of the survey respondents can be considered as symptomatic: "It actually depends on all parties .... in my previous school any assessment was the absolute humiliation, it was neither objective nor professional ... currently, I am in a school, where it is exactly opposite ... But assessment is never in vain ... one can also learn from the negative experience ... critical open mind of a teacher whose aim should be continuous selfassessment and efforts to move forward stands above all assessment outcomes... ".

The standpoint of the assessed on the psychological effect of the assessment is based on these considerations. It is gratifying that in our survey 488 teachers $(73 \%)$ consider assessment as something what motivates them. On the contrary, 100 teachers (15\%) stated that it is demotivating, 54 teachers $(8 \%)$ considered it useless and 11 teachers (2\%) marked the option 'other'. Oral comments in the box "other" have recorded the range of responses from neutral "I have no idea" through attitudinal "I do not want to comment on it", and to ignorant "I do not want to have any opinion and, particularly, to express it in any questionnaire!!!" Interestingly enough, the percentages of the psychological impact of the assessment expressed by teachers largely correspond with the statements of head teachers, out of which $71 \%$ believe that the evaluation has motivating effects on teachers. Unlike the assessed, not a single respondent from the head teachers has marked it as discouraging. The percentage of the uselessness of evaluation is higher $(15 \%)$ as expressed by the evaluators than by the evaluated $(8 \%)$. From oral comments it is, however, obvious that the reservations stated by the head teachers are predominantly connected with the range of the carried assessment and the means of its implementation.

\section{Conclusion}

Considering even the partial research results achieved on the national level - the significant motivating value and impact of assessment on teaching performance of teachers on the one hand, but not a high willingness of head teachers to perform this activity (as majority of them delegate assessment duty to their deputies) on the other hand, and some hesitations about the issue whether and how to make teachers aware about assessment conclusions in a fair way, made the research team confident to believe in meaningfulness of their research and the tasks they wanted to undergo within the following years of the project life - to design new approaches to teachers' assessment and offer upgraded, based on prior piloting and discussion with the stakeholders, tools and instruments for teachers' assessment, as well as criteria and guidelines how to use them. The research team believes that new challenges for school education in $21^{\text {st }}$ century also have to find their reflection in the ways how teachers are assessed in order to make the assessment process more standardized and objective. Last but not least, another objective is to make it less stressful, in order to make more teachers friendly and humanistic.

\section{Acknowledgement}

This work was supported by the Slovak Research and Development Agency under the contract APVV-14-0446.

\section{References}

[1] Magová, L. et al. (2016) Hodnotenie kompetencii učitel'ov v európskom a slovenskom kontexte. (Transl.: Evaluation of teachers' competences in the European and Slovak context). Praha: Verbum.

[2] Gadušová, Z., \& Hašková, A. (2017). Results of An On-line Survey on Competence Profiles of Primary and Secondary School Teachers. In Teaching and Learning with Technology: Proceedings of the 2016 Global Conference on Teaching and Learning with Technology (CTLT 2016) (pp. 271-281).

[3] Viteckova, M., Prochazka, M., Gadusova, Z., \& Stranovska, E. (2016, November). Identifying novice teacher's needs-The basis for novices' targeted support. In Proceedings of ICERI2016 Conference (pp. 7731-7738).

[4] Fandelová, E., Gadušová, Z., \& Lomnický, I. (2016). Head Teachers Perception of Teacher's Oral and Written Assessment. Efficiency and Responsibility in Education (pp.113-120).

[5] Z. Gadusova, B. Hockickova, I. Lomnicky, L. Predanocyova, R. Zilova .(2016). Evaluation Of Teachers' Competences, Inted 2016 Proceedings, pp. 6957-6965.

[6] Gadusova, Z., Haskova, A., \& Predanocyova, E. (2019). Teachers' professional competence and their evaluation. Образование и саморазвитие, 14(3), 1724.

[7] Slavík, J. (1999). Hodnoceni v současné škole: východiska a nové metody pro praxi. Portál, sro. 